\section{Cervical Cytology in General Practice}

SIR,-In the summer of 1963 a cytological service became available. I have since taken routine smears at post-natal examinations and whenever vaginal examination was indicated. On a few occasions I have failed to obtain a suitable specimen. No attempt has been made to screen patients who would not otherwise have been examined, and I have only started taking smears from patients on oral contraceptives this month. No request has been made for a smear in spite of the widespread publicity.

Practising in a group it is not possible to state the exact number of patients for whom I am responsible, but a fair estimate would be 2,800 . When it occurred to me that the figures might be of interest, our cytologist $\mathrm{Dr}$. Margaret Wolfendale kindly analysed the smears I had sent in.

To the middle of November 1964141 smears had been taken of which $47 \%$ were post-natal specimens. The monthly rate was nine, and I had picked up one carcinoma in situ, subsequently confirmed. Assuming that $25 \%$ of my patients are women in the significant age-group, without modifying my pattern of practice $20 \%$ of my patients have been examined, and within three years of starting the figure may rise to half my population. Some women will be re-examined, but I believe my monthly rate will rise as I add the contraceptive-taking group.

It is only fair to state that my rate is rather higher than that of other family doctors making use of the service; facilities for the examination of smears are limited anyway.

The Lancet, discussing Professor Scott's Mackenzie Lecture, ${ }^{1}$ points out that general practice is perpetually if inconspicuously absorbing the techniques of the hospital, thereby relieving special departments of part of their load. This can only happen if practitioners are not too heavily burdened to accept new responsibilities, and at present few of us feel our lot is so comfortable that we can extend our services in new directions without restrictions elsewhere.

I have not seen estimates of the rate of screening in routine family practice previously, but I now feel that progressive examination of a practice population can be carried out. It is probable, however, that this can only be done in practices that at sacrifice to themselves have kept their list size within bounds and employed adequate ancililary help.-I am, etc.,

Bletchley, Bucks.

GrofFrey RivetT.

\section{RBPBRRNCB}

1 Lancet, 1964, 2, 1161.

\section{Immunofluorescent Diagnosis of Amoebiasis}

SIR,-The recent article by Dr. J. D. Fulton and Dr. A. Voller ( 7 November, p. 1173) dealing with the application of the indirect fluorescent-antibody technique to the detection of specific Toxoplasma antibodies prompts me to give a preliminary report on the results of similar studies made in this department in cases of systemic Infection with another protozoon, Entamoeba histolytica.

Sera giving a positive amoebic complementfixation test were obtained from three patients with evidence of hepatic amoebiasis. In addition, control sera were obtained from six healthy subjects, eight patients with nonamoebic liver disorders, and 21 patients with other non-amoebic conditions. Smears of $E$. histolytica were treated first with a $1 / 8$ dilution of each of the 38 sera, and subsequently with fluorescein-labelled anti-human-globulin. Microscopic examination of the smears was made using ultra-violet light excitation in conjunction with a-dark-ground condenser. Brilliant $(++++)$ fluorescence of the amoebae was obtained with the sera from each of the three patients with amoebiasis (see Fig.), in striking contrast to the weak fluorescent staining obtainable with the control sera.

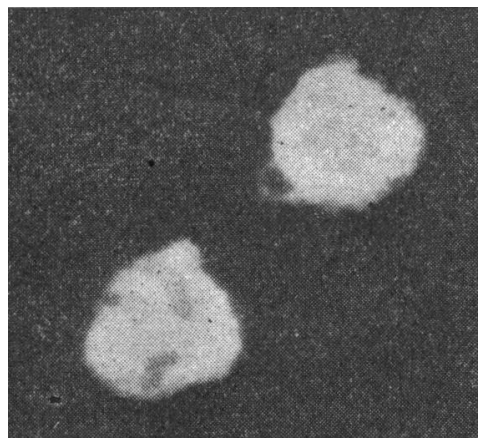

Positive immunofluorescent staining of Entamoeba histolytica obtained with $1: 8$ dilution of serum from patients with hepatic amoebiasis. $(\times 2,000$. $)$

Further tests of sensitivity and specificity are in progress, and we would be very glad to receive sera from colleagues with known or suspected cases of intestinal or hepatic amoebiasis. In the meantime it seems likely that this versatile technique is capable of playing a useful part in the elucidation of what may, as stated in your leading article (25 July, p. 206), be a difficult diagnostic problem.

I wish to thank Dr. G. L. Robinson, of the Dreadnought Seamen's Hospital, Greenwich, who performed the complement-fixation tests and provided me with two of the test sera and also with cultures of $E$. histolytica. I also thank Mr. F. J. Gibbs, F.I.M.L.T., for his assistance.

-I am, etc.

$$
\begin{aligned}
& \text { Department of Clinical Pathology, } \\
& \text { Guy's Hospital, } \\
& \text { London S.E.1. }
\end{aligned}
$$

\section{Fires and Explosions}

SIR,-I notice that Mr. K. J. Carroll in his memorandum on "Unusual Explosions During Electrosurgery" (7 November, p. 1178) mentioned that such explosions have occurred as the result of the eructation of inflammatory gases.

I recall a case referred to me by $\mathrm{Dr}$. Ronald Hartley many years ago. The patient was a parson who became alarmed when he noticed that his breath took fire every time he blew the altar candles out. I performed a Polya-gastrectomy for a duodenal ulcer causing pyloric stenosis, following which he was able to carry out his duties in a more decorous fashion.-I am, etc.,

Royal London Homoeopathic StePhen Power. Hospital,

\section{Abdominal Paracentesis}

SIR,-The trocar and cannula for abdominal paracentesis ${ }^{1}$ referred to in the leading article of 26 September (p. 774) is an elegant instrument. House-physicians are rarely offered such equipment and many use an unnecessarily large trocar and cannula which is unpleasant for the patient and leaves a track for infection. Aspiration is very easy with a serum needle attached to clamped tubing, and sterile equipment is readily available by adapting a plastic drip set. Only a weal of local anaesthetic is required. Patients who require repeated aspiration find this a very simple procedure.-I am, etc.,

Glasgow N.1.

I. I. J. M. Gibson.

REFERENCB

Kerr, D. N. S., Pearson, D. T., and Read, A. B., Gut, 1963, 4, 394.

\section{Circumcision and Cervical Cancer}

SIR,-As pointed out in your leading article on "Circumcision and Cervical Cancer" (15 August, p. 397), the value of male circumcision in the prevention of cancer of the cervix is still uncertain. It would be wrong, however, to dismiss its possible beneficial effect. In a 10-year (1954-64) survey from the Sudan ${ }^{1}$ comparison has been made between Khartum Civil Hospital series and a district hospitals series. Almost $100 \%$ of women attending the Khartum Civil Hospital were married to Muslim men, who are fully circumcised at an early age, whereas in the district hospitals series an unknown proportion, estimated at 10 to $15 \%$, were from the Southern Provinces, where male circumcision is not practised commonly. The findings of a frequency-ratio study based upon surgical biopsy material showed a lower incidence of cervical carcinoma in the Khartum Civil Hospital series. It also disclosed a pattern of site distribution more approximating that of Western countries than those of other African states. Thus breast cancer formed $23.3 \%$ and cervical cancer $13.1 \%$ of the total malignancy in the

\begin{tabular}{|c|c|c|c|c|c|c|}
\hline \multicolumn{7}{|c|}{$\begin{array}{l}\text { Site Distribution and Percentage Incidence of } \\
\text { Cancers of the Genital Tract and Breast in } \\
\text { Sudanese Women (1954-1964) }\end{array}$} \\
\hline \multirow[t]{2}{*}{ Site } & \multicolumn{2}{|c|}{$\begin{array}{c}\text { Khartum } \\
\text { Civil } \\
\text { Hospital }\end{array}$} & \multicolumn{2}{|c|}{$\begin{array}{c}\text { District } \\
\text { Hospitals }\end{array}$} & \multicolumn{2}{|c|}{ Total } \\
\hline & No. & $\%$ & No. & $\%$ & No. & $\%$ \\
\hline $\begin{array}{l}\text { Vulva .. } \\
\text { Vagina .. } \\
\text { Corpus } \\
\text { Cervix .. } \\
\text { Chorion- } \\
\text { epitheli- } \\
\text { oma }\end{array}$ & $\begin{array}{r}14 \\
2 \\
31 \\
86\end{array}$ & $\begin{array}{r}2 \cdot 1 \\
0 \cdot 3 \\
4 \cdot 7 \\
13 \cdot 1\end{array}$ & $\begin{array}{r}15 \\
7 \\
36 \\
170\end{array}$ & $\begin{array}{r}1.6 \\
0.7 \\
3.8 \\
18 \cdot 0\end{array}$ & $\begin{array}{r}29 \\
9 \\
67 \\
256\end{array}$ & $\begin{array}{r}1 \cdot 8 \\
0 \cdot 6 \\
4 \cdot 2 \\
16 \cdot 0\end{array}$ \\
\hline $\begin{array}{l}\text { Fallopian } \\
\text { tube } \\
\text { Ovary } \\
\text { Breast } \\
\text { Other }\end{array}$ & $\begin{array}{r}2 \\
30 \\
153\end{array}$ & $\begin{array}{r}0 \cdot 3 \\
4 \cdot 6 \\
23 \cdot 3\end{array}$ & $\begin{array}{r}0 \\
77 \\
203\end{array}$ & $\begin{array}{r}0 \cdot 0 \\
8 \cdot 2 \\
21 \cdot 5\end{array}$ & $\begin{array}{r}2 \\
107 \\
356\end{array}$ & $\begin{array}{r}0 \cdot 1 \\
6 \cdot 7 \\
22 \cdot 2\end{array}$ \\
\hline otal .. & 657 & 100.0 & 945 & $100 \cdot 0$ & 1,602 & $100 \cdot 0$ \\
\hline
\end{tabular}
Khartum Hospital series (see Table). Since

Note: The above tahle is reproduced by kind permission of the Editor, Sudan med. $\mathcal{F}$.

several alleged causes of cervical cancer (early and multiple marriages, coitus at a young age, malnutrition, liver disease) probably operate in the Sudan to a greater extent than in Western countries, it was concluded that the 